\title{
Mathematical Model of Flower Stalk Development in Chinese Cabbage in Relation to High Temperature Effect Combined with Low Temperature Effect
}

\author{
Keiichiro Mori, Hiromi Eguchi and Tsuyoshi Matsui \\ Biotron Institute, Kyushu University, Fukuoka 812, Japan
}

(Received December 8, 1979)

\begin{abstract}
The mathematical model of flower stalk development in Chinese cabbage was developed in relation to high temperature effect combined with low temperature effect. Fifteen days old seedlings treated with $5^{\circ} \mathrm{C}$ for 10 days under artificial light and day length of 8 hours, were treated again with 25,30 and $35^{\circ} \mathrm{C}$ for durations of 5 and 10 days under continuous lighting. After the treatments, plants were grown under $20^{\circ} \mathrm{C}$ and continuous lighting. The pattern of flower stalk development was fitted in time course to the logistic curve and was approximated to the first order lag curve which was used as the model.

The rise of flower stalk development in the treatments with higher temperatures of 25 , 30 and $35^{\circ} \mathrm{C}$ after the low temperature treatment was delayed much more as compared with that under $20^{\circ} \mathrm{C}$ (untreatment with higher temperatures) after the low temperature treatment, but the difference in rise was observed scarcely among degrees of the higher temperatures. Thus, it could be conceivable that temperatures higher than at least $25^{\circ} \mathrm{C}$ decreased the low temperature effect on the rise of flower stalk development. For determining the time of delay in its rise, sum of the time constant and the dead time was used as a parameter. So, $\log _{10} \Delta T^{1 / 2} \cdot t_{d^{2}}$ obtained in previous paper to evaluate the low temperature effect on the time of delay was compensated by high temperatures of 25 to $35^{\circ} \mathrm{C}$ after the low temperature treatment, as denoted by $\log _{10} H \Delta T^{1 / 2} \cdot t_{d^{2}}$ on the time of delay, where $\Delta T, t_{d}$ and $H$ are a degree of the subtraction of treating low temperature from untreating temperature $\left(20^{\circ} \mathrm{C}\right)$, treating duration with low temperature and the function of treating duration with higher temperatures, respectively. That is, the $\log _{10} H \Delta T^{1 / 2} \cdot t_{d}^{2}$ was used as a parameter evaluating the high temperature effect combined with the low temperature effect. Thus, the effect of low temperature on flower stalk development was decreased multiplicatively by higher temperatures after the low temperature treatment as expressed by the parameter $(H)$ evaluating the effect of higher temperatures, which exists within the range of 0 to 1.0 .
\end{abstract}

The model of the plant responses to environmental factors can be considered to be effective for evaluating the functions of environment in plant growth and development. ${ }^{1-6)}$ In previous papers, the mathematical model of flower stalk development in Chinese cabbage has been presented by using the parameters which evaluate the effects of low temperature, temperature dropping gradient and photoperiod. ${ }^{7-9)}$ In general, there are many cases that the low temperature effects on plant morphogeneses are reversed or decreased by higher temperatures. ${ }^{10-15)}$ The present paper deals with quantitative evaluation of the effect of higher temperatures on the flower stalk development in Chinese cabbage after the low temperature treatment, in relation to high temperature effect combined with low temperature effect. 
Plant material. Chinese cabbage, Brassica pekinensis Rupr. "Nagaoka-kohai taibyo-rokujunichi" was used. This species is known to be sensitive to low temperature and photoperiod in flower stalk development (bolting). Plants were grown under air temperature of $20 \pm 2^{\circ} \mathrm{C}$, air humidity of $75 \pm 10 \% \mathrm{RH}$ and day length of 8 hours with light intensity of about $300 \mu \mathrm{Em}^{-2} \mathrm{sec}^{-1}$ (metal halide lamp).

Treatment. Fifteen days old seedlings ( 2 leaves stage) were treated with the low temperature of $5 \pm 1^{\circ} \mathrm{C}$ for respective durations of $3,6,9,10,12,15,18$ and 21 days under artificial light (20 white fluorescent lamps of $40 \mathrm{~W}$ and 5 tungsten lamps of $200 \mathrm{~W}$ ) with intensity of about $200 \mu \mathrm{Em}^{-2} \mathrm{sec}^{-1}$ and day length of 8 hours, using 8 plants per experimental plot for the purpose of reaffirming the low temperature effect. The plants treated with the low temperature of $5^{\circ} \mathrm{C}$ for 10 days were treated again with respective temperatures of $25 \pm 1,30 \pm 1$ and $35 \pm 1{ }^{\circ} \mathrm{C}$ for different durations of 5 and 10 days and continuous lighting with the same light intensity and quality as those in the low temperature treatment. After the treatments, plants were grown under continuous lighting (metal halide lamps) with light intensity of about $300 \mu \mathrm{Em}^{-2} \mathrm{sec}^{-1}$ at $20 \pm 2^{\circ} \mathrm{C}$ and $75 \pm 10 \% \mathrm{RH}$.

\section{RESULTS AND DISCUSSION}

\section{Examination of flower stalk development}

The flower stalk development was examined by measuring a distance between the cotyledonary node and shoot apex every three days. Figure 1 shows the patterns of flower stalk development in respective treatments. There is no significant difference in final length of flower stalk among the treatments with respective temperatures of $20,25,30$ and $35^{\circ} \mathrm{C}$ after the low temperature treatment. While, the rise of flower

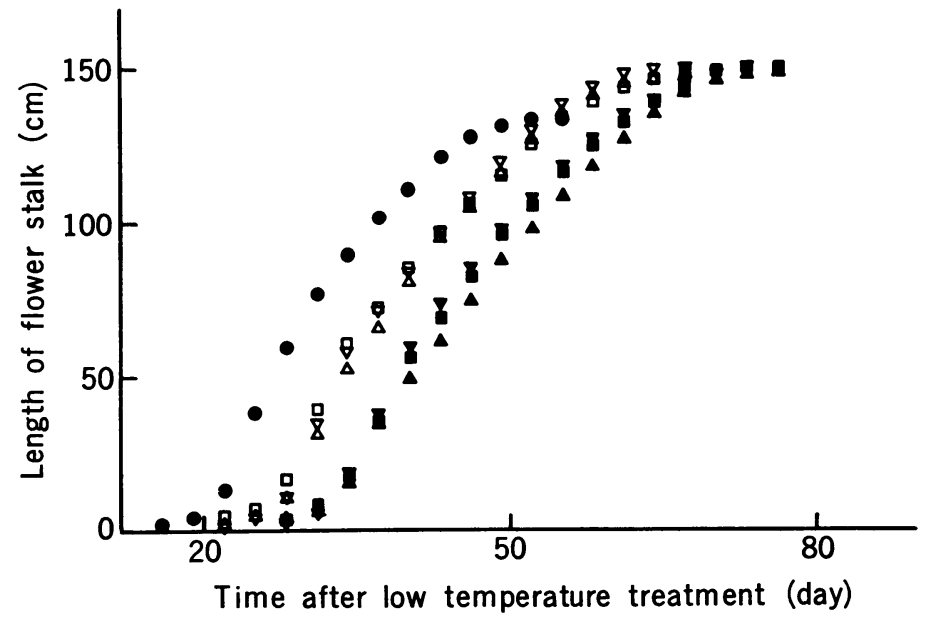

Fig. 1 Patterns of flower stalk development in respective treatments with higher temperatures after low temperature treatments.

$\triangle, 25^{\circ} \mathrm{C}$ for 5 days; $\Delta, 25^{\circ} \mathrm{C}$ for 10 days; $\square, 30^{\circ} \mathrm{C}$ for 5 days; $\square, 30^{\circ} \mathrm{C}$ for 10 days; $\nabla, 35^{\circ} \mathrm{C}$ for 5 days; $\nabla, 35^{\circ} \mathrm{C}$ for 10 days; $\bullet$, treatment with only low temperature. 


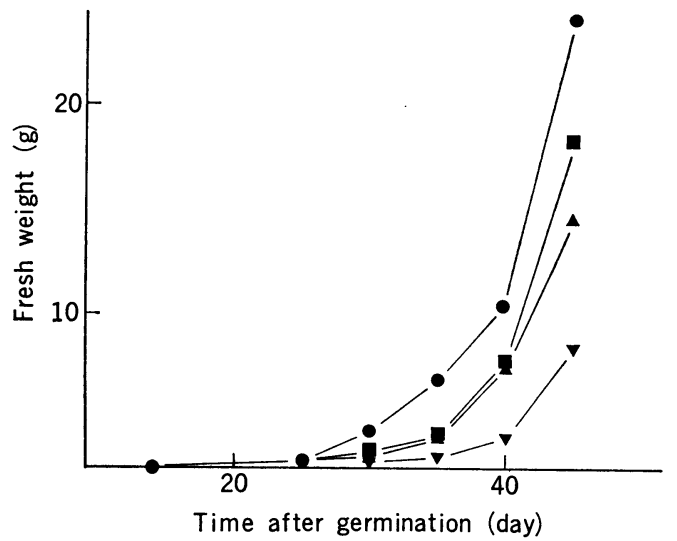

Fig. 2 Increase in fresh weight per plant for treating duration of 10 days with different higher temperatures after low temperature treatment.

$\Delta, 25^{\circ} \mathrm{C} ; \boldsymbol{\square}, 30^{\circ} \mathrm{C} ; \boldsymbol{\nabla}, 35^{\circ} \mathrm{C} ; \boldsymbol{\bullet}$, treatment with only low temperature.

stalk development in the treatments with higher temperatures of 25,30 and $35^{\circ} \mathrm{C}$ after the low temperature treatment was delayed much more as compared with that under a temperature of $20^{\circ} \mathrm{C}$ (untreatment with higher temperatures) after the low temperature treatment. Distinct difference in the delay in rise of flower stalk development was observed among treating durations with higher temperatures: The longer treating durations with higher temperatures increased in delay in its rise. But, the difference in delay was observed scarcely among degrees of the higher temperatures, in spite of decrease in fresh weight in proportion to degrees of higher temperatures as shown in Fig. 2. Thus, it could be conceivable that there is the same effect of higher temperatures on flower stalk development within range of 25 to $35^{\circ} \mathrm{C}$, that is, temperatures higher than at least $25^{\circ} \mathrm{C}$ decrease the low temperature effect on flower stalk development.

\section{Mathematical representation}

In order to evaluate the effect of higher temperatures on flower stalk development after the low temperature treatment, the relation between flower stalk development and higher temperatures was analyzed statistically: The pattern of flower stalk development was fitted in time course to the logistic curve. ${ }^{16)}$ For examining this curve, the asymptote and the delay in its rise were represented by using the temperature conditions as the parameters. Figure 3 shows final length of flower stalk and its $95 \%$ confidence interval in respective treatments. The difference in final length of flower stalk was not significant at $5 \%$ level among all treatments. So, the asymptote of the equation of the logistic curve was given as the mean value $(151.32 \mathrm{~cm})$ of the final lengths of flower stalk in all treatments.

As mentioned before, the delay in rise of flower stalk development was affected by higher temperatures after the low temperature treatment. In order to examine the delay, the same statistical processing as that in previous paper ${ }^{7)}$ was employed: The equation of the logistic curve was approximated to that of the first order lag curve having the same value of asymptote and the same differential coefficient at $63.2 \%(1-1 / e)$ of asymptote as those of the logistic curve, as shown in Fig. 4. The 


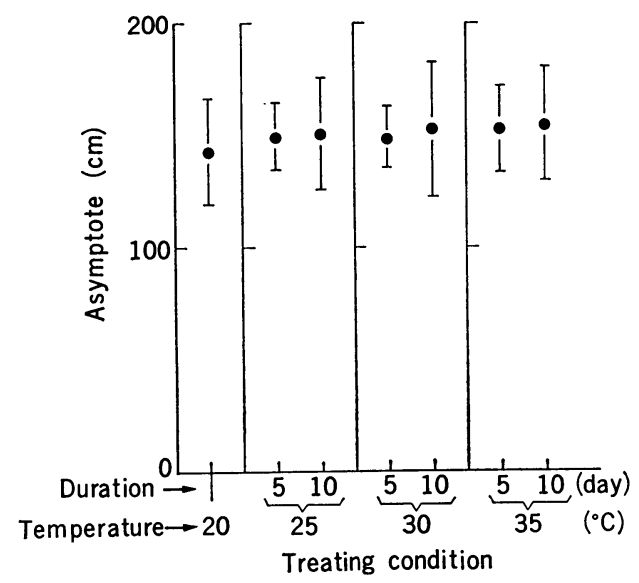

Fig. 3 Final length of flower stalk and its $95 \%$ confidence intervals in respective treatments.

๑, measured value of final length of flower stalk; $I$, its $95 \%$ confidence interval.

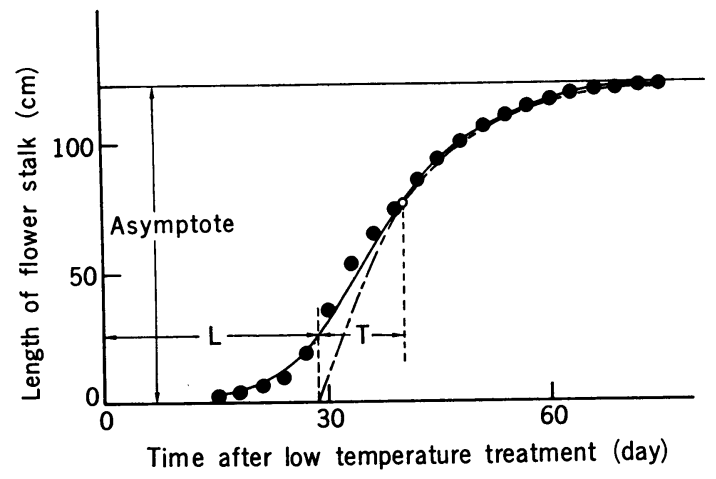

Fig. 4 Definition of evaluation of flower stalk development.

- measured value of flower stalk; —-, logistic curve fitting to measured values; -..-, curve of first order lag approximating to the logistic curve.

sum of the time constant ( $T$, day) and the dead time ( $L$, day) of the first order lag curve was used as a parameter determining the time of delay. The previous paper reported that the correlation coefficient of the time of delay on $\log _{10} \Delta T^{1 / 2} \cdot t_{d}^{2}$ is highest among the various combinations of $\Delta T$ and $t_{a}$ with significance at $0.1 \%$ level, where $\Delta T$ is a degree of the subtraction of treating temperature from untreating temperature $\left(20^{\circ} \mathrm{C}\right) .^{7}$ In present experiment, the correlation coefficient of measured time $\left(D_{d}\right.$, day) of delay on $\log _{10} \Delta T^{1 / 2} \cdot t_{d}^{2}$ was also high $(r=0.985$, significant at $0.1 \%$ level) enough to use $\log _{10} \Delta T^{1 / 2} \cdot t_{a}^{2}$ for evaluation of the low temperature effect under the same treating conditions as that in previous paper. ${ }^{7)}$ Figure 5 shows relation between $D_{d}$ and $\log _{10} \Delta T^{1 / 2} \cdot t_{d}^{2}$. The regression equation of $D_{d}$ was given by

$$
D_{d}=81.6-18.0 \log _{10} \Delta T^{1 / 2} \cdot t_{d}^{2}
$$




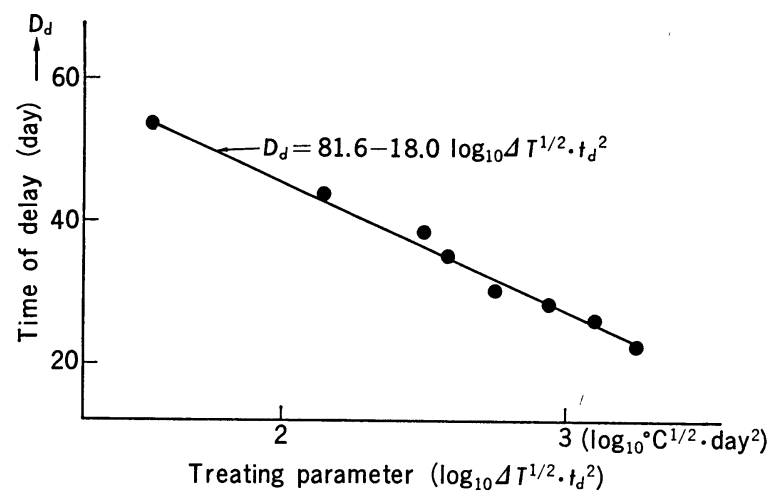

Fig. 5 Relation between the time $\left(D_{d}\right)$ of delay and the parameter $\left(\log _{10} \Delta T^{1 / 2} \cdot t_{d}^{2}\right)$ evaluating low temperature effect in treatment with only low temperature.

On the other hand, the time of delay in its rise was clearly affected by higher temperatures after the low temperature treatment as mentioned before. So, the time of delay could be represented by the parameters consisting of treating conditions of higher temperatures. That is, $\log _{10} \Delta T^{1 / 2} \cdot t_{d}^{2}$ evaluating the low temperature effect could be compensated by the higher temperatures, as denoted by $\log _{10} H \Delta T^{1 / 2} \cdot t_{d}^{2}$ on the time of delay, where the coefficient $(H)$ is the function of treating duration with higher temperatures. In the case untreated with higher temperatures, $H$ should become 1.0, and Eq. (1) is used for representing the time of delay. Figure 6 shows distribution of $H$ on treating duration with higher temperatures. Thus, the $H$ was represented as a function of treating duration $\left(h_{d}\right.$, day) with higher temperatures of 25 to $35^{\circ} \mathrm{C}$ after the low temperature treatment, because the $H$ was not affected by degrees of treating higher temperatures. The regression equation was given by

$$
H=9.18 \times 10^{-1}-1.74 \times 10^{-1} h_{d}+9.55 \times 10^{-3} h_{d^{2}}
$$

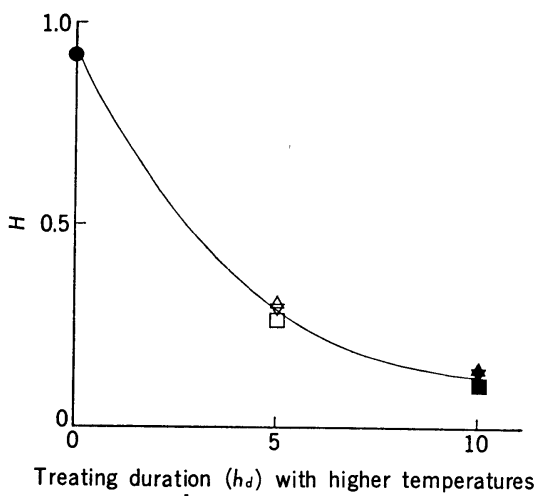

Fig. 6 Distribution of the parameter $(H)$ on treating duration with higher temperatures.

$\triangle, 25^{\circ} \mathrm{C}$ for 5 days; $\boldsymbol{\Delta}, 25^{\circ} \mathrm{C}$ for 10 days; $\square, 30^{\circ} \mathrm{C}$ for 5 days; $\boldsymbol{\square}, 30^{\circ} \mathrm{C}$ for 10 days; $\nabla, 35^{\circ} \mathrm{C}$ for 5 days; $\nabla, 35^{\circ} \mathrm{C}$ for 10 days; $\bullet$, treatment with only low temperature. 


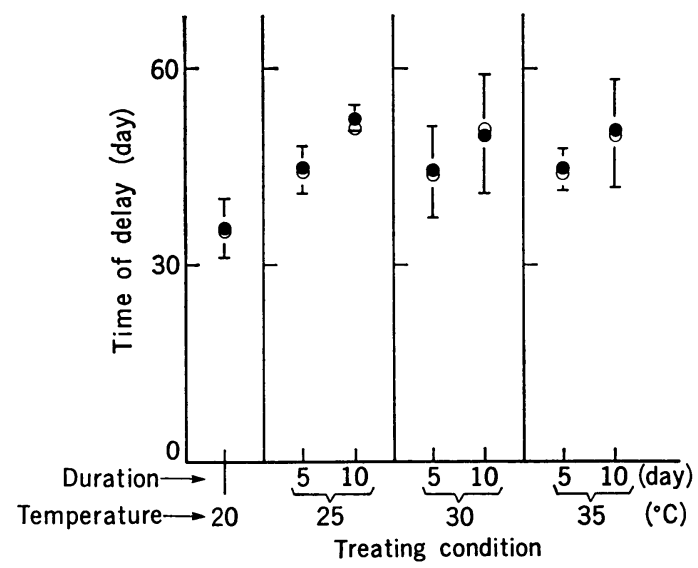

Fig. 7 Measured time of delay, its 95\% confidence interval and the time $(D)$ of delay calculated from Eq. (3) in respective treatments.

- measured time of delay; $\underline{I}$, its $95 \%$ confidence interval; $\bigcirc$, the time $(D)$ of delay calculated from Eq. (3).

where $h_{d}$ is the treating duration $\left(10 \geqq h_{d} \geqq 0\right)$ with higher temperatures of 25 to $35^{\circ} \mathrm{C}$. From Eqs. (1) and (2), the time $(D$, day) of delay in rise of flower stalk development was represented by the function of $\Delta T, t_{d}$ and $h_{d}$,

$$
\begin{gathered}
D=81.6-18.0 \log _{10}\left\{\left(9.18 \times 10^{-1}-1.74 \times 10^{-1} h_{a}\right.\right. \\
\left.\left.+9.55 \times 10^{-3} h_{a^{2}}\right) \Delta T^{1 / 2} \cdot t_{d}^{2}\right\}
\end{gathered}
$$

Figure 7 shows measured time of delay, its $95 \%$ confidence interval and the time $(D)$ of delay calculated from Eq. (3) in respective treatments. The $\log _{10} H \Delta T^{1 / 2} \cdot t_{d}^{2}$ could be useful as a parameter evaluating the high temperature effect combined with

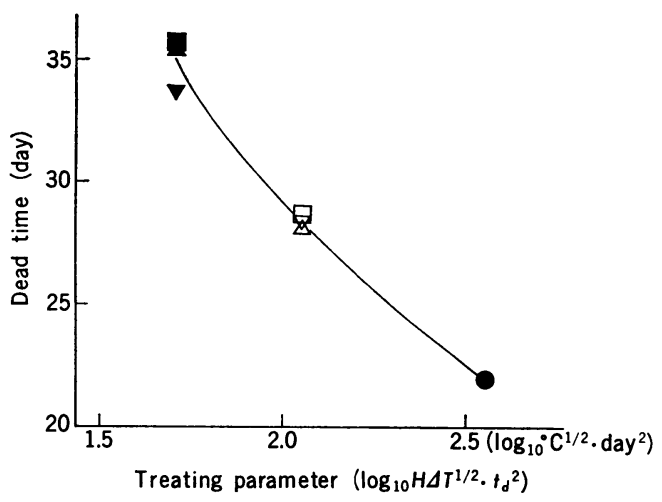

Fig. 8 Relation between the dead time $(L)$ and the parameter $\left(\log _{10} H \Delta T^{1 / 2} \cdot t_{d}{ }^{2}\right)$ evaluating the higher temperature effect combined with low temperature effect in respective treatments with higher temperatures after low temperature treatment.

$\triangle, 25^{\circ} \mathrm{C}$ for 5 days; $\Delta, 25^{\circ} \mathrm{C}$ for 10 days; $\square, 30^{\circ} \mathrm{C}$ for 5 days; $\square, 30^{\circ} \mathrm{C}$ for 10 days; $\nabla, 35^{\circ} \mathrm{C}$ for 5 days; $\nabla, 35^{\circ} \mathrm{C}$ for 10 days; $\bullet$, treatment with low temperature. 
the low temperature effect on the delay. As shown in Fig. 6, the parameter $(H)$ distributed below 1.0 in all treatments with higher temperatures. This fact indicated that the low temperature effect on the time of delay is decreased multiplicatively by higher temperatures after the low temperature treatment.

Figure 8 shows the relation between the dead time and $\log _{10} H \Delta T^{1 / 2} \cdot t_{d}{ }^{2}$. The regression equation of the dead time $\left(L\right.$, day) on $\log _{10} H \Delta T^{1 / 2} \cdot t_{d^{2}}$ was given by

$$
L=87.6-41.0 \log _{10} H \Delta T^{1 / 2} \cdot t_{d}^{2}+5.95\left(\log _{10} H \Delta T^{1 / 2} \cdot t_{d}^{2}\right)^{2}
$$

As mentioned before, the equation of the logistic curve of flower stalk development was approximated to that of the first order lag curve having an asymptote $\left(K_{s}\right)$ of $151.32 \mathrm{~cm}$ and satisfying Eqs. (3) and (4). So, the length of flower stalk $\left(Y_{s}, \mathrm{~cm}\right)$ was given by

$$
Y_{s}=K_{s}\left[1-\exp \left\{g\left(t_{p}\right)\right\}\right]
$$

where $t_{p}$ is days after the low temperature treatment, and $g\left(t_{p}\right)=L / T-t_{p} / T{ }^{16)}$ This model of flower stalk development was expressed as

$$
\begin{aligned}
Y_{s}= & 151.32 \times\left[1-\exp \left[\left\{87.6-41.0 \times \log _{10} H \Delta T^{1 / 2} \cdot t_{d}{ }^{2}\right.\right.\right. \\
& \left.+5.95 \times\left(\log _{10} H \Delta T^{1 / 2} \cdot t_{d}^{2}\right)^{2}-t_{p}\right\} /\{-6.00+23.0 \\
& \left.\left.\left.\times \log _{10} H \Delta T^{1 / 2} \cdot t_{d}^{2}-5.95 \times\left(\log _{10} H \Delta T^{1 / 2} \cdot t_{d}^{2}\right)^{2}\right\}\right]\right]
\end{aligned}
$$

where $18 \geqq \Delta T \geqq 9,20 \geqq t_{d} \geqq 5$ as examined in previous papers, ${ }^{7,8} \quad 10 \geqq h_{d} \geqq 0$ and $77 \geqq t_{p} \geqq 0$.

\section{Conclusion}

Figure 9 shows examples of the curves calculated from Eq. (6) and measured values of flower stalk in respective treatments. From the fact that the calculated

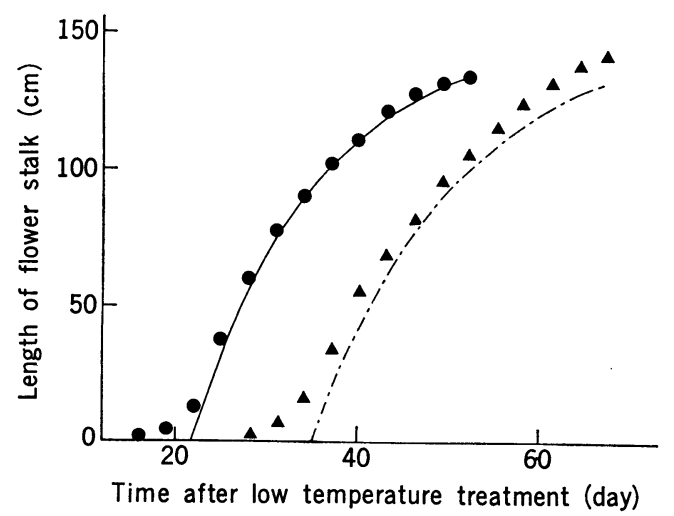

Fig. 9 Comparison of measured values of flower stalk in treatment with higher temperatures after low temperature treatment and curves of the model calculated from Eq. (6).

-.--, curve in treatment with $30^{\circ} \mathrm{C}$ for 10 days; —_, curve in untreatment with higher temperatures; $\boldsymbol{\Delta}$, measured values of flower stalk in treatment with $30^{\circ} \mathrm{C}$ for 10 days; $\bullet$, measured values of flower stalk in untreatment with higher temperatures. 
curves were close to the measured values, it was estimated that Eq. (6) is enough to be used as the model of flower stalk development. Thus, it became clear that the treating duration $\left(h_{a}\right)$ with higher temperatures of 25 to $35^{\circ} \mathrm{C}$ is also useful as the parameter in the mathematical model of flower stalk development, which was expressed in general as follows,

$$
\begin{aligned}
Y_{s}= & F\left[f_{1}\left(t_{m}\right)+f_{2}\left(t_{m}, d_{l}\right) \cdot f_{3}\left(t_{d}\right)\right] \cdot G\left[g_{1}\left(T_{l}, t_{m}\right)\right. \\
& \left.+g_{2}\left(t_{m}, d_{l}, h_{d}\right) \cdot g_{3}\left(T_{l}, t_{d}\right)+g_{4}\left(t_{p}\right)\right]
\end{aligned}
$$

where $Y_{s}, t_{m}, d_{l}, t_{d}, T_{l}, h_{d}$ and $t_{p}$ are the length of flower stalk, a period settling to $5^{\circ} \mathrm{C}$, day length, treating duration with low temperature, treating low temperature, treating duration with higher temperatures after the low temperature treatment and time after the low temperature treatment, respectively.

The $\log _{10} \Delta T^{1 / 2} \cdot t_{d}^{2}$ evaluating the low temperature effect on flower stalk development was modified with the compensating function $(H)$ of treating duration $\left(h_{d}\right)$ with higher temperatures of 25 to $35^{\circ} \mathrm{C}$, and the $\log _{10} H \Delta T^{1 / 2} \cdot t_{d}^{2}$ was used as a parameter evaluating the high temperature effect combined with the low temperature effect on flower stalk development. The present model made it clear that the rise of flower stalk development affected by the low temperature is delayed by higher temperatures, that is, the effect of low temperature on flower stalk development is decreased multiplicatively by the higher temperatures, as expressed by Eq. (2) where the parameter $(H)$ evaluating the effect of higher temperatures exists within the range of 0 to 1.0 .

\section{REFERENCE}

1) YAMASAKI, K. 1956. Thermo-stage for the green plant of Chinese cabbage grown in spring. Bull. Hortic. Div. Tokai-Kinki Agric. Exp. Sta. 1: 31-47 (in Japanese).

2) WANG, J. Y. 1960. A critique of the heat unit approach to plant response studies. Ecology 41: 785-790.

3) ARon, R. H. 1975. A method for estimating the number of hour below a selected temperature threshold. J. Appl. Metherol. 14: 1415-1418.

4) Wiebelt J. A., and J. B. Henderson. 1978. Theoretical thermal modeling of a leaf with experimental verification. Agric. Meteorol. 19: 101-111.

5) Tyldesley J. B. 1978. A method of evaluating the effect of temperature on an organism when the response is non-linear. Agric. Meteorol. 19: 137-153.

6) Matsui, T., H. EgUChI, and K. Mori. 1977. Mathematical model of low temperature effect on female flower formation of cucumber plants in phytotron glass rooms. Environ. Control in Biol. 15: 1-9.

7) Matsui, T., H. Eguchi, and K. Mori. 1978. Mathematical model of flower stalk development in Chinese cabbage in response to low temperature. J. Fac. Agric. Kyushu Univ. 22: 233-241.

8) Mori, K., H. Eguchi, and T. Matsui. 1979. Mathematical model of flower stalk development in Chinese cabbage affected by low temperature and photoperiod. Environ. Control in Biol. 17: 17-26.

9) Mori, K., H. Eguchi, and T. Matsui. 1979. Mathematical model of flower stalk development in Chinese cabbage affected by low temperature dropped with gradient in course of time. Environ. Control in Biol. 17: 141-152.

10) Tetjurev, V. A. 1941. How long can vernalized winter wheat plants be treated with high temperature affecting their development. C. R. (Dokl.) Akad. Sci. URSS 30: 189-190.

11) Efeikin, A. K. 1941. Devernalization of vernalized winter wheats. C. R. (Dokl.) Akad. Sci. 
URSS 30: 661-663.

12) Sen, B., and S. C. Chakravarti. 1946. Effect of high temperature on vernalized mustard seed. Nature 157: 266.

13) Purvis O. N., and F. G. Gregory. 1952. Studies in Vernalization. XII. The reversibility by high temperature of the vernalized condition in Petkus winter rye. Ann. Bot (London) [N. S.] 16: 1-21.

14) Overcash J. P., and J. A. Campbell. 1955. The effect of intermittent warm and cold periods on breaking the rest period of peach leaf buds. Am. Soc. Hortic. Sci. 66: 87-92.

15) Friend D. J. C., and O. N. Purvis. 1963. Studies in vernalization of cereals. XIV. The thermal reactions in vernalization. Ann. Bot. (London) [N.S.] 27: 553-579.

16) Richards, F. J. 1969. The quantitative analysis of growth. In "Plant Physiology" Vol. VA (Ed. by Steward, F. C.) 3-76, Academic Press, New York and London.

$<$ 和文抄録 $>$

\section{低温と高温の組合せ効果に関する白菜花茎伸長の数式モデル}

\section{森 啓一郎・江口弘美・松井 健}

九州大学生物環境調節センター

植物の生育および分化に関与する環境要因の作用を量的に評価するために, 前報において白菜の花茥 伸長に作用する低温, 温度降下公配および日長をパラメータとした数式モデルを報告した. 本報におい ては花茎伸長に対する低温処理後の高温の作用を評価し，その評価パラメータを組み入れた数式モデル に発展させることを試みた。春播白菜「長岡交配耐病六十日」を用い播種 15 日目に 8 時間日長 (人工 光) 条件で低温 $\left(5^{\circ} \mathrm{C}\right)$ 処理を行い, 処理後 24 時間日長条件で高温 $\left(25,30,35^{\circ} \mathrm{C}\right)$ 処理を行った. その 結果, 高温の作用は花茎の最終值に対してはほとえど認められなかったが, 花茎伸長の立ち上りの遅れ に明瞭であった。 そこで花茥伸長の立ち上りの遅れを花茥伸長に近似する 1 次遅れ式の時定数とむだ 時間の和として評価した．前報で決定した立ち上りの遅れに対する低温の効果の評価パラメータ $\log _{10} \Delta T^{1 / 2} \cdot t_{d}{ }^{2}\left(\Delta T=20^{\circ} \mathrm{C}\right.$ 一低温処理温度, $t_{d}$ は低温処理時間）に高温条件をパラメータとして組み入 れて, $H$ を高温処理時間の関数とした場合, $\log _{10} H \Delta T^{1 / 2} \cdot t_{d}{ }^{2}$ が低温の効果と高温の効果を組み合せて 立ち上りの遅れを評価しうることがわかった．このモデルから，白菜の花茎伸長に対する低温の効果は， 低温処理後の温度によっても異なり，高温評価パラメータ $(H)$ はつねに 1.0 以下となっていることから， 高温 $\left(25 \sim 35^{\circ} \mathrm{C}\right)$ は低温の効果を積の形で減少させることが明らかになった。 